\title{
'N STERKTEPERSPEKTIEF OP BEMAGTIGENDE MAATSKAPLIKE GROEPWERK MET ALKOHOLAFHANKLIKE BEJAARDES
}

\section{LS Geyer, H Strydom}

\section{INLEIDING}

In hierdie artikel word daar by die kenmerke van die sterkteperspektief asook die houdings en persepsies van maatskaplike werkers teenoor dié perspektief stilgestaan. In die teks word die agtergrond van die sterkteperspektief, die sterktes van alkoholafhanklike bejaardes, die rol van dié perspektief in geregistreerde behandelingsentra in Suid-Afrika asook die voor- en nadele van dié perspektief onder meer toegelig. Die doelwitte van hierdie artikel is (a) om deur middel van literatuurstudie en empiriese ondersoek die uitdagings, sterktes en behoeftes van alkoholafhanklike bejaardes te identifiseer waarop ' $n$ maatskaplike groepwerk-bemagtigingsprogram gebaseer kan word, en (b) vas te stel oor watter kwaliteite die sterkteperspektief beskik ten einde die alkoholafhanklike bejaarde met maatskaplike groepwerkdienste te bemagtig.

\section{AGTERGROND EN NAVORSINGSMETODOLOGIE}

Die sterkteperspektief is een van die praktykperspektiewe in die Maatskaplike Werk wat 'n pleidooi lewer vir 'n verandering in die hart en gees van maatskaplikewerk-dienslewering (Saleebey, 2001:221; Smith, 2002). Dié perspektief stel 'n aanpasbare, pluralistiese en relativistiese mensbeeld voor waarin daar holisties na kliënte gekyk word (Murphy \& Pardeck, 1998:5). Daarteenoor is die teenpool, 'n probleemgesentreerde benadering, geskoei op 'n dualistiese mensbeeld wat meestal teenoorgesteldes onderskei (Pardeck \& Murphy, 1993:11871189).

Verskeie outeurs, soos Early en GlenMaye (2000:118-119), McQuaide en Ehrenreich (1997:202) asook Van Wormer (1999:4), rapporteer dat die sterkteperspektief reeds benut is op uiteenlopende diensterreine van maatskaplike werk soos persone met verstandelike gebreke, bejaardes, substansafhanklike persone en hersaamgestelde gesinne.

In die lig hiervan is daar besluit om deur middel van literatuurstudie en 'n empiriese ondersoek vas te stel oor watter kwaliteite die sterkteperspektief beskik ten einde die alkoholafhanklike bejaarde te bemagtig. Voorts is vasgestel oor watter sterktes dié kliëntegroep beskik. Terselfdertyd is die benutting van dié perspektief, binne die konteks van geregistreerde behandelingsentra, verken. Ten einde die voorgenoemde navorsingsdoelwitte te bereik, is ontwikkelings- en benuttingsnavorsing (Strydom, 2000:151-158) onderneem volgens 'n gemengde metodologiese navorsingsmodel (De Vos, 2005b:359-362).

Ses-en-vyftig ( $\mathrm{N}=56)$ alkoholafhanklike bejaardes van 58 jaar en ouer is betrek deur middel van 'n doelgerigte en sneeubalsteekproef (Babbie, 2004:183-184; Strydom, 2005b:201-203). Die deelnemers is geïdentifiseer by geregistreerde behandelingsentra, asook in die CAD en CAB geledere. 'n Aanpassing van die ouderdomsperk was nodig weens die aanvanklike beperkte deelnemertal. Die gemiddelde ouderdom van die deelnemers was sowat 66 jaar $(60,55)$ ten tyde van die ondersoek.

Daarteenoor is $27 \quad(\mathrm{~N}=27)$ maatskaplike werkers verbonde aan nege geregistreerde behandelingsentra betrek deur middel van 'n beskikbaarheidsteekproef (Babbie, 2004:183-184). Aangesien die universum beperk is, is ' $n$ beskikbaarheidsteekproef gebruik vir hierdie ondersoek. Babbie (2004:183-184) en Strydom (2005b:201-203) meld dat 'n doelgerigte en 
sneeubalsteekproef veral geskik is in gevalle waar die deelnemers moeilik geïdentifiseer en byeengebring word. Juis om hierdie rede is die vermelde steekproewe geskik vir 'n ondersoek soos hierdie.

Onderhoudskedules, volgens 'n opnameprosedure, is vir data-insameling benut. 'n Opnameprosedure is 'n navorsingsmetode waarvolgens data versamel word uit 'n geselekteerde steekproef om die kenmerke of menings van die populasie te beskryf (Strydom, 2000:117). Onderhoudskedules is met bejaarde deelnemers in Suid-Afrika voltooi ten einde die behoeftes, sterktes en uitdagings van alkoholafhanklike bejaardes te identifiseer. In hierdie artikel is die fokus op die sterktes van die kliëntegroep. Voorts is onderhoudskedules ook met maatskaplikewerkdeelnemers voltooi om fasette soos bestaande dienste aan alkoholafhanklike bejaardes te verken.

Oop vrae, byvoorbeeld: "Meen $u$ dat u oor sterktes beskik?" en "Indien u 'ja' geantwoord het, noem asseblief hierdie sterktes." is benut ten einde die bejaarde deelnemers se persepsies van bepaalde sake fenomenologies te ondersoek (Delport \& Fouché, 2005:264). Die kwalitatiewe data is deur die navorsers self verwerk deurdat sentrale en subtemas doelgerig ontleed is (De Vos, 2005a:337-338). Daarbenewens is enkele geslote en geskaleerde vrae (Strydom, 2000:124-131) ook aan die deelnemers gerig. Die maatskaplikewerk-deelnemers is byvoorbeeld gevra "Is $u$ bekend met die sterkteperspektief?" Kwantitatiewe data is statisties verwerk met die statistiese rekenaarpakket, SAS System for Windows (SAS Institute Inc., 2002-2005) deur 'n statistiese konsultasiediens.

Etiese oorwegings, soos geen ongerief aan die deelnemers, ingeligte toestemming tot deelname asook die handhawing van vertroulikheid, is op hierdie ondersoek van toepassing (Mitchell \& Jolley, 2001:138-139; Monette, Sullivan \& DeJong, 2005:53-61; Strydom, 2005a:57-67).

\section{ONTSTAAN VAN DIE STERKTEPERSPEKTIEF}

Vervolgens word die ontstaan van die sterkteperspektief slegs binne maatskaplike werk in SuidAfrika bespreek. Die breër internasionale konteks van dié perspektief is reeds breedvoerig binne Amerikaanse vakliteratuur bespreek (McMillen, Morris \& Sherraden, 2004).

\section{SUID-AFRIKAANSE KONTEKS}

Die onderhawige bespreking word aangebied deur te verwys na drie tydperke binne die SuidAfrikaanse maatskaplikewerk-geskiedenis (Potgieter, 1973:25-48; Van Dyk, 2001:22-31; Van Eeden, Ryke \& De Necker, 2000:1-24):

\section{- Pre-Apartheid Suid-Afrika (1652-1948)}

Die sterkteperspektief is nie 'n nuwe benadering in die Maatskaplike Werk nie (Gray \& Van Rooyen, 2002:193; Weick \& Saleebey, 1998:27; Weick, Rapp, Sullivan \& Kisthardt, 1989:353). Reeds sedert die ontstaan van die maatskaplikewerk-professie het die inherente kragte, potensiaal en sterktes van mense erkenning geniet. Die Maatskaplike Werk het in die westerse wêreld, en eweneens in Suid-Afrika, vanuit hoofsaaklik 'n naastediens ontwikkel tot 'n selfstandige professie (Kotze, 2002:45-55; Kotze, 2003:4-13).

Aanvanklik was gesinne hoofsaaklik op hulself aangewese om in hul eie behoeftes te voorsien, maar sedert die totstandkoming van die eerste NG Kerk in 1665 het dié instelling tesame met die regering van die dag, die Kompanjie, armsorgwerk onder behoeftiges gedoen (Potgieter, 1973:2527). Alhoewel die voorgenoemde samewerking tot gekategoriseerde, gesentraliseerde en gekontroleerde hulpverlening aanleiding gegee het, was daar steeds geen georganiseerde welsynsdienste beskikbaar nie (Potgieter, 1973:26-27). Nietemin is daar nie bloot aandag geskenk 
aan die fisiese en materiële nood van mense nie, maar sorgbehoewende persone is ook van psigiese en geestelike hulpverlening voorsien (Potgieter, 1973:25-27). Dienslewering aan die alkoholis, aldus Potgieter (1973:83-84), was beperk tot die rehabilitasie van misdadigers (vgl. Wet op Gevangenissen en Verbetergestichten) en die isolasie van onder meer alkoholiste deur middel van werkskolonies soos dié van die Rand Aid Association (vgl. Werkkoloniewet, 1927). Die eerste selfhelpgroep, Alkoholiste Anoniem (AA), het in 1946 in Johannesburg tot stand gekom. Maatskaplikewerk-dienslewering is dus ooreenkomstig 'n probleemgesentreerde benadering beoefen met uitsondering van selfhelpgroepe wat reeds 'n element van selfbemagtiging bevat het.

\section{- Apartheid in Suid-Afrika (1948-1994)}

Suid-Afrika het vóór die totstandkoming van die demokratiese ANC-regering 'n welsynsbeleid gevolg wat hoofsaaklik op 'n residuele en institusionele benadering gebaseer was (Lombard, 1996:164-165; Mkhwanazi \& Triegaardt, 2003:49-50; Van Dyk, 2001:12-15; Van Eeden et al., 2000:20-22). In hierdie era het verskeie welsynsdienste tot stand gekom vanuit private en staatsinisiatief. Dienste was egter afsonderlik op die verskillende rassegroepe in Suid-Afrika gerig (Van Eeden et al., 2000:7-11).

Die residuele benadering het 'n maatskaplikewerk-praktyk voorgestel waarvolgens persone slegs vir hulpverlening in aanmerking gekom het, indien hulle nie met behulp van hul gesinne en ander gemeenskapstrukture in hul eie behoeftes kon voorsien nie (Van Dyk, 2001:12). Gevolglik is maatskaplikewerk-dienste gewoonlik volgens gevallewerk gelewer met die oog op die rehabilitasie van kliënte deur hoofsaaklik statutêre ingrepe (Mkhwanazi \& Triegaardt, 2003:50; Van Eeden et al., 2000:20-21). Maatskaplikewerk-ingrepe, ingevolge hierdie benadering, het dikwels tot die stigmatisering van kliënte aanleiding gegee (Mkhwanazi \& Triegaardt, 2003:50).

In teenstelling met die voorgenoemde benadering was die institusionele benadering gebaseer op die aanname dat maatskaplikewerk-aktiwiteite 'n normale funksie van die moderne samelewing is (Mkhwanazi \& Triegaardt, 2003:50; Van Dyk, 2000:14). Volgens hierdie benadering is 'n verskeidenheid dienste tot die beskikking van die samelewing gestel soos dienssentrums vir bejaardes (Lombard, 1996:165). Die voorgenoemde veronderstel 'n positiewe ingesteldheid wat op die voortgesette maatskaplike verbetering van kliënte gemik was (Van Dyk, 2001:15).

In hierdie tydperk is daar verskeie behandelingsentra, private en staatsinisiatief, in Suid-Afrika opgerig vir die rehabilitasie van alkoholiste (vgl. Wet op toevlugte en rehabilitasiesentrums, 86/1963; Wet op die misbruik van afhanklikheidsvormende stowwe en rehabilitasiesentrums, 41/1971 \& Wet op die voorkoming en behandeling van dwelmafhanklikheid, 20/1992, soos gewysig). Daar is egter ook aandag gegee aan voorkomings- (bv. AA-groepe), rekonstruksie- en nasorgdienste (Potgieter, 1973:95-98). Op grond van die voorafgaande word die afleiding gemaak dat hierdie era steeds deur probleemgesentreerde dienslewering oorheers is, alhoewel maatskaplikewerk-dienste nie slegs tot remediërende aksie beperk was nie.

\section{- Demokratiese Suid-Afrika (1994 - )}

Met die bewindsoorname van die ANC-regering in 1994 word die Suid-Afrikaanse welsynsbeleid, ooreenkomstig die White Paper for Social Welfare, gebaseer op 'n ontwikkelingsmodel (SA, 1997:15, 57). Laasgenoemde model is versoenbaar met die sterkteperspektief aangesien mense se sterktes aktief geïdentifiseer en benut word tot voordeel van hul eie ontwikkeling. 'n Ontwikkelingsmodel streef na die maatskaplike opheffing van die samelewing in verskeie funksioneringsareas soos behuising, ekonomie, gesondheid en welsyn (Lombard, 1996:165; Van Dyk, 2001:15). Insgelyks is welsynsdienste hervorm tot 'n nie-rassige diens ooreenkomstig beginsels soos demokrasie, gelykheid en toeganklikheid (SA, 1997:12, 16-17). 
Maatskaplikewerk-dienslewering aan die substansafhanklike persoon in hierdie era is eweneens versoenbaar met 'n sterkteperspektief, aangesien die bemagtiging en ontwikkeling van kliënte onderskryf word, selfs op die tersiêre voorkomingsvlak (SA, 1999:27-28). Tersiêre voorkomingsdienste, volgens die National Drug Master Plan, ondersteun steeds dienslewering in behandelingsentra, maar nie vanuit probleemgesentreerde benaderings nie, aangesien kapasiteitsbou onderskryf word (SA, 1997:81-83). Voorts behoort dienste ook pertinent te fokus op voorheen benadeelde populasies soos bejaardes (Patel \& Wilson, 2003:223-224). Terselfdertyd omskryf die White Paper for Social Welfare dit duidelik dat maatskaplikewerk-dienste aan die substansafhanklike persoon ook voorsiening moet maak vir voorkomingsdienste, gemeenskapsgebaseerde behandeling en nasorgdienste, benewens institusionalisering in behandelingsentra (SA, 1997:82).

Vanuit die voorafgaande bespreking blyk dit dat die sterkteperspektief reeds die afgelope dekade in Suid-Afrikaanse welsyn erkenning geniet en die toepassing daarvan verwelkom word.

\section{DEFINISIE VAN DIE STERKTEPERSPEKTIEF}

Alhoewel verskeie outeurs, soos McMillen et al. (2004), Norman (2000), Rapp (1998) asook Van Wormer en Davis (2003), uiteenlopende bydraes oor die sterkteperspektief lewer, ontbreek 'n omvattende definisie deurdat verskeie teksboeke en vaktydskrifte huiwer om dié perspektief te definieer. Vanweë die resente aard van die sterkteperspektief verskyn daar ook geen definisie in die beskikbare vaktaalwoordeboeke nie.

In die lig van die vermelde leemte, word 'n sintese uit al die genoemde outeurs se sienings soos volg gemaak:

"Die sterkteperspektief dui op 'n filosofie van maatskaplikewerk-dienslewering waarvolgens die fokus op patologie van kliënte doelbewus vervang word deur klem te plaas op die gesondheid, sterktes, talente en veerkragtigheid van kliënte as vennote in 'n bemagtigingsproses."

Vanuit die voorafgaande definisie kan die volgende afleidings gemaak word:

- Die sterkteperspektief is 'n praktykperspektief en nie 'n volwaardige teorie nie, want dit is 'n "filosofie."

- Die sterkteperspektief ontken nie dat kliënte wel probleme ondervind nie, maar fokus eerder op die sterktes, suksesse, talente en vaardighede waaroor hulle beskik.

- Vanuit 'n sterkteperspektief is die kliënt nie bloot 'n ontvanger van maatskaplikewerk-dienste nie, maar 'n aktiewe vennoot in 'n bemagtigingsproses.

- Aangesien die kliënte bemagtig word, word hulle gemotiveer om self uitdagings te hanteer met die ondersteuning van hul inherente en eksterne sterktes asook dié van die betrokke maatskaplike werker. Die kliënte word gevolglik nie gemotiveer tot passiwiteit nie, maar wel om eie inisiatief aan die dag te lê by die hantering van uitdagings.

- Die sterkteperspektief erken dat kliënte probleme ondervind, maar is daarvan oortuig dat die kliëntsisteem oor die sterktes beskik, of kan ontwikkel, om daaruit te ontspring soos 'n veer. Vandaar die gedagte van veerkragtigheid. 


\section{STERKTES VAN ALKOHOLAFHANKLIKE BEJAARDES}

Vir die doeleindes van hierdie ondersoek is dit nodig geag om die sterktes van die bejaarde deelnemers te verken sodat dit enersyds in 'n maatskaplike groepwerk-bemagtigingsprogram vervat kan word, en andersyds 'n klemverskuiwing vanaf patologie kan meebring.

Met die uitvoering van die empiriese ondersoek is die sterktes van alkoholafhanklike bejaardes soos volg ondersoek:

- Eerstens is die alkoholafhanklike bejaardes $(\mathrm{N}=56)$ versoek om die sterktes waaroor hulle individueel beskik, te vermeld en te evalueer. Hierdie vraag is slegs aan die deelnemers gestel wat van mening was dat hulle wel oor sterktes beskik.

- Tweedens is die maatskaplike werkers $(\mathrm{N}=27)$ versoek om die sterktes van alkoholafhanklike bejaardes in die algemeen aan te dui. (Sien die paragrawe by agtergrond/navorsingsmetodologie vir 'n breedvoerige verduideliking van die empiriese ondersoek.)

Die bevindings in hierdie verband kan soos volg saamgevat word:

\section{PERSPEKTIEF VAN BEJAARDES}

Met die voltooiing van die onderhoudskedules is elke bejaarde deelnemer gevra of hy/sy van mening is dat hy/sy oor sterktes beskik. In hierdie ondersoek het 55 (98.21\%) deelnemers verklaar dat hulle oor sterktes beskik, terwyl een (1.79\%) die teenoorgestelde standpunt gehuldig het.

Ter ansluiting by die vorige vraag is elke deelnemer die geleentheid gebied om sy/haar individuele sterktes aan te dui. Die deelnemers $(\mathrm{N}=55)$ se kwalitatiewe response (meer as een respons per deelnemer is moontlik) op hierdie vraag was soos volg:

- Persoonlikheidseienskappe soos perfeksionisme en selfkennis ( $\mathrm{f}=55$ ).

- Ondersteuningsnetwerke soos die familie, huweliksmaat en kerk ( $\mathrm{f}=52$ ).

- Godsdiens ( $\mathrm{f}=25)$.

- Beroepsuitnemendheid ( $\mathrm{f}=21)$.

- Stokperdjies ( $\mathrm{f}=18)$.

- Talente soos musiek en skilderkuns ( $\mathrm{f}=15)$.

- Goeie gesondheid ( $\mathrm{f}=12)$.

- Hoë intelligensie ( $\mathrm{f}=4)$.

- $\operatorname{Humorsin}(\mathrm{f}=3)$.

- Leierseienskappe ( $\mathrm{f}=3)$.

- Verblyfomstandighede wat algemene geluk bevorder $(\mathrm{f}=3)$.

- Stabiele finansiële posisie ( $\mathrm{f}=1)$.

Vanuit die voorafgaande is dit duidelik dat die bejaarde deelnemers oor 'n wye verskeidenheid sterktes beskik. Hierdie sterktes verteenwoordig die ekonomiese, fisiese, psigiese, sosiale en religieuse dimensies waarin die mens funksioneer. 
Volgens die hoë-frekwensie response is sekere persoonlikheidseienskappe, ondersteuningsnetwerke, godsdiens en beroepsuitnemendheid uitgesonder. Met die ontwikkeling en aanbieding van 'n groepwerk-bemagtigingsprogram behoort sodanige sterktes aangewend te word om bejaardes te bemagtig. Dit is moontlik aangesien nie slegs uitdagings geïdentifiseer en hanteer word nie, maar ook die sterktes waaroor die kliënt beskik (Kivnick \& Murray, 2001:19).

Volgens McQuaide en Ehrenreich (1997:202), wat ook kliënte se sterktes in die algemeen verken het, is kliënte geneig om meestal sterktes soos lojaliteit, goeie luistervermoë, intelligensie en 'n sin vir humor aan te toon. Laasgenoemde outeurs meen dit is tipiese antwoorde van ' $\mathrm{n}$ kliënt wat nie daaraan gewoond is om hom-/haarself met sterktes te assosieer nie.

Vanuit die voorafgaande word die afleiding gemaak dat die alkoholafhanklike bejaardes enersyds oor die vermoë beskik om hulle sterktes te identifiseer en te kommunikeer, maar andersyds moontlik aan maatskaplikewerk-praktyke, waarin 'n sterkteperspektief geïmplementeer is, blootgestel is. Hierdie afleiding word gemaak omdat die bejaarde deelnemers in staat was om 'n verskeidenheid sterktes te noem en nie slegs dié wat deur McQuaide en Ehrenreich (1997:202) as algemeen bestempel word nie.

\section{PERSPEKTIEF VAN MAATSKAPLIKE WERKERS}

Soos vroeër vermeld, is ook die maatskaplikewerk-deelnemers $(\mathrm{N}=27)$ versoek om die sterktes van alkoholafhanklike bejaardes in die algemeen aan te dui. Die kwalitatiewe response op hierdie vraag was soos volg:

- $\quad$ Lewenservaring $(\mathrm{f}=19)$.

- Mensekennis $(\mathrm{f}=8)$.

- Lewenswysheid ( $\mathrm{f}=7)$.

- Lewenstevredenheid en -aanvaarding ( $\mathrm{f}=5)$.

- Leierseienskappe ( $\mathrm{f}=4)$.

- Steunstelsels soos die familie, gemeenskap en gesin ( $f=4)$.

- $\quad$ Empatie met naasbestaandes $(\mathrm{f}=3)$.

- $\operatorname{Godsdiens}(\mathrm{f}=2)$.

- Kulturele trots $(\mathrm{f}=2)$.

- Persoonlikheidseienskappe soos mededeelsaamheid en rustigheid ( $f=2)$.

Vanuit die voorafgaande is dit duidelik dat sterktes soos lewenservaring, mensekennis, lewenswysheid, lewenstevredenheid en aanvaarding prominent aangedui is. Hierdie sterktes, asook andere, behoort dus vervat te word in die ontwikkeling en aanbieding van 'n groepwerkbemagtigingsprogram met alkoholafhanklike bejaardes.

Indien die response van die maatskaplike werkers vergelyk word met dié van die bejaardes, is dit duidelik dat die eersgenoemde groep heelwat minder sterktes aangetoon het. Die maatskaplike werkers het byvoorbeeld glad nie sterktes soos humorsin, stokperdjies en talente aangedui nie. Hieruit kan die volgende afleidings geformuleer word:

- Die bejaarde deelnemers het moontlik hulle sterktes oorskat en gevolglik meer sterktes as die maatskaplike werkers aangedui. 
- Die feit dat die maatskaplikewerk-deelnemers heelwat minder sterktes vermeld het, mag daarop dui dat hulle oorwegend vanuit 'n probleemgesentreerde benadering maatskaplikewerk-dienste lewer.

Benewens die voorafgaande is outeurs, soos Cowger en Snively (2002:118-120), McQuaide en Ehrenreich (1997:206), Rapp (1998:78-79) asook Waller (2001:22-25), dit eens dat die response, soos die voorgenoemde, wel sterktes is wat in maatskaplikewerk-dienslewering vanuit 'n sterkteperspektief benut word. Die voorgenoemde sterktes behoort dus opgeneem te word in 'n maatskaplike groepwerk-bemagtigingsprogram met alkoholafhanklike bejaardes.

\section{ROL VAN DIE STERKTEPERSPEKTIEF IN GEREGISTREERDE BEHANDELINGSENTRA}

Rhodes en Johnson (1996:182) meen dat die probleemgesentreerde praktykbenadering steeds in die VSA die benadering van keuse in chemiese afhanklikheidsgesentreerde dienslewering is, alhoewel die sterkteperspektief vir etlike dekades bestaan en reeds met intervensie navorsing suksesvol bevind is (Rapp, 2002:135-136).

In die lig van die voorafgaande is dit nodig geag om ondersoek in te stel na die toepassing van die sterkteperspektief in geregistreerde behandelingsentra in Suid-Afrika. Voorts is die houding en persepsies van Suid-Afrikaanse maatskaplike werkers jeens die sterkteperspektief ondersoek.

\section{STERKTEPERSPEKTIEF IN MAATSKAPLIKEWERK-DIENSLEWERING}

Ten tyde van die empiriese ondersoek is die maatskaplikewerk-deelnemers $(\mathrm{N}=27)$ gevra of hulle bekend is met die sterkteperspektief. Die oorgrote meerderheid $(55.56 \%)$ is onbekend met hierdie perspektief van maatskaplikewerk-dienslewering. Slegs twaalf $(44.44 \%)$ maatskaplike werkers het aangedui dat hulle bekend is met dié perspektief. Hieruit kan afgelei word dat die sterkteperspektief enersyds 'n resente praktykperspektief is wat nog nie in Suid-Afrika bekend is nie. Andersyds kan dit daarop dui dat Suid-Afrikaanse maatskaplike werkers dikwels nie op hoogte bly met die nuutste ontwikkelinge in die maatskaplikewerk-professie nie, ofskoon $44.44 \%$ van die deelnemers reeds ten tyde van die ondersoek oor 'n nagraadse kwalifikasie beskik het. By persone met nagraadse kwalifikasies sou 'n professionele nuuskierigheid om op hoogte te bly met nuwe ontwikkelings te wagte wees, maar dit blyk nie op hierdie ondersoekgroep van toepassing te wees nie. Dit kan moontlik daaraan toegeskryf word dat die maatskaplikewerk-deelnemers nie voortdurend vaktydskrifte lees waarin nuwe tegnologie, soos die sterkteperspektief, bekendgestel en bespreek word nie. Voorts mag dit daarop dui dat die deelnemers nie voortgesette professionele leergeleenthede bywoon nie.

Diegene wat onbekend is met die sterkteperspektief is oorsigtelik daaraan bekendgestel. Dit is gedoen voordat die volgende vraag aan die deelnemers gestel kon word. Die maatskaplike werkers is vervolgens gevra of hulle die idees en beginsels van die sterkteperspektief benut in hul maatskaplikewerk-dienste. Drie-en-twintig (85.19\%) deelnemers het verklaar dat hulle die beginsels benut, teenoor vier $(14.51 \%)$ deelnemers wat die teenoorgestelde beweer het. Vanuit die voorafgaande word die afleiding gemaak dat alhoewel die meeste maatskaplike werkers met die sterkteperspektief as sodanig onbekend is, die idees en beginsels van hierdie perspektief wel in 'n mindere of meerdere mate toegepas word.

Die deelnemers wat aangedui het dat hulle wel met die sterkteperspektief bekend is, is gevra om aan te dui hoe hulle dié perspektief in maatskaplikewerk-dienste benut. Die kwalitatiewe response hierop was soos volg: 
- Die kliënte word nie toegelaat om hulself as slagoffers van hul omstandighede te beskou nie.

- Maatskaplikewerk-dienslewering bou voort op suksesse van die verlede. Die kliënt word herinner aan suksesse wat hy reeds behaal het, ter motivering vir volgehoue betrokkenheid by die hulpverleningsproses.

- Die kliënte se lewenservaring word as 'n sterkte erken en benut in maatskaplikewerkdienslewering.

- Erkenning word gegee vir elke mylpaal wat die kliënte behaal soos die onthouding van alkohol in 'n spanningsvolle situasie waar hy normaalweg sou swig voor alkohol.

- Die kliënt word gemotiveer tot eienaarskap van sy uitdagings.

- Die kliënt prioritiseer self die uitdagings wat hanteer word in vennootskap met 'n maatskaplike werker.

- Die maatskaplike werker en kliënt se fokus is veral toekomsgerig.

Alhoewel die voorafgaande kwalitatiewe response wel waar mag wees, blyk dit duidelik dat dit grotendeels aanpassings is van die beginsels van 'n sterkteperspektief. Die beginsels van die sterkteperspektief kom in essensie neer op die volgehoue vertroue in die kliënt se vermoë om te groei, te verander en te ontwikkel (Kisthardt, 2002:165-172; Saleebey, 2002a:13-18). Die afleiding kan dus gemaak word dat die maatskaplike werkers 'n perspektief gebruik wat hulle as die sterkteperspektief beskou, terwyl dit nie werklik daarop gegrond is nie. Een deelnemer het aangedui dat sy nie 'n sterkteperspektief gebruik nie omdat sy nie daarmee bekend is nie. Gesien in die lig van die voorafgaande word afgelei dat die maatskaplikewerk-deelnemers onbekend is met die sterkteperspektief. Aangesien dit 'n vinnig-groeiende perspektief van dienslewering is, behoort maatskaplike werkers opleiding hierin te ontvang. Dit dui daarop dat dié deelnemers, asook moontlik talle maatskaplike werkers in Suid-Afrika, 'n behoefte het aan skoling in die sterkteperspektief.

\section{HOUDINGS EN PERSEPSIES}

Vir die doeleindes van hierdie ondersoek is dit nodig geag om nie net die maatskaplikwerkdeelnemers se kennis en benutting, al dan nie, van die sterkteperspektief te verken nie, maar eweneens hulle houdings en persepsies jeens dié praktykperspektief. Die rede hiervoor is ondermeer om die maatskaplike werkers se professionele opinie omtrent die sterkteperspektief te verken.

Die maatskaplike werkers wat by hierdie ondersoek betrek is, handhaaf gemengde houdings en persepsies teenoor maatskaplikewerk-dienslewering vanuit 'n sterkteperspektief. Diegene wat 'n positiewe gesindheid handhaaf, het motiverings soos die volgende aangevoer:

- "Dit is belangrik, want dit verhoog die kliënt se lewenskwaliteit."

- "Dit behoort wyer in dienslewering geïmplementeer te word."

- "Word aanbeveel."

- "Fokus totaal op die positiewe in die pasiënt."

Benewens die positiewe gesindhede was enkele deelnemers negatief teenoor maatskaplikewerkdienslewering vanuit hierdie perspektief. Redes soos die volgende is aangevoer: 
- "Behandeling van alkoholiste behoort hoofsaaklik medies- en probleemgesentreerd aangepak te word."

- "Moeilik, aangesien daar 'n multiprofessionele diens gelewer word. Die ander professies werk meestal probleemgeoriënteerd."

Laasgenoemde is uiteraard 'n geldige beswaar aangesien alkoholafhanklike bejaardes uiteenlopende behoeftes ervaar wat nie net deur maatskaplike werkers hanteer kan word nie. Gevolglik word maatskaplike werkers genoodsaak om praktyke te volg waarmee al die lede van die multiprofessionele span bekend is.

Met betrekking tot alkoholafhanklikheid is hierdie gemengde response moontlik toe te skryf aan onbekendheid met die sterkteperspektief enersyds en die dominering van 'n siektebenadering andersyds. Om alkoholafhanklikheid vanuit 'n siektebenadering te benader, het voor- en nadele. Enersyds het dit die voordeel dat dit die funksionering van die multiprofessionele span vergemaklik en eise van mediese fondse vergemaklik. Andersyds het dit die nadeel dat dit die maatskaplike werkers daarvan weerhou om dienste aan alkoholiste te lewer vanuit 'n sterkteperspektief waar kliënte waarskynlik met nuwe moed vir die toekoms toegerus kon word.

\section{VOOR- EN NADELE VAN DIE STERKTEPERSPEKTIEF}

Alhoewel die sterkteperspektief wêreldwyd 'n relatief nuwe gedagte in die maatskaplikewerkpraktyk is, behoort dit soos enige ander praktykperspektief of -model geëvalueer te word. Om hierdie rede is daar in hierdie ondersoek pogings aangewend om vas te stel wat die voor- en nadele van maatskaplikewerk-dienslewering vanuit 'n sterkteperspektief is. Hierdie faset van die ondersoek is soos volg uitgevoer:

- Eerstens is die maatskaplikewerk-deelnemers versoek om, volgens hul mening, die voor- en nadele van 'n sterkteperspektief aan te dui.

- Tweedens is die voorgenoemde response oorsigtelik met vakliteratuur, van maatskaplike werk in die algemeen, vergelyk.

\section{Voordele}

Volgens die maatskaplikewerk-deelnemers ( $\mathrm{N}=27)$ hou maatskaplikewerk-dienslewering vanuit 'n sterkteperspektief die volgende voordele in:

- Die sterkteperspektief skep ruimte waarbinne kliënte saam met die maatskaplike werker in 'n bemagtigingsproses betrokke raak. Die kliënt word dus nie bloot van sy probleme verlos nie, maar word bemagtig om self uitdagings te hanteer $(\mathrm{f}=7)$.

- Die sterkteperspektief verskaf hoop aan die kliënt dat hy wel oor die inherente en eksterne sterktes beskik om sy uitdagings te hanteer $(\mathrm{f}=6)$.

- Kliënte se selfwaarde word uitgebou. Dit is moontlik aangesien die kliënt bewus word van sy sterktes te midde van die dikwels oorweldigende uitdagings. Die alkoholafhanklike persoon is byvoorbeeld skaam om voor mense te praat, maar oorbrug hierdie vrees deur deel te neem aan gesprekke tydens groepbyeenkomste. Die maatskaplike werker kan die kliënt hiervan bewus maak en hom terselfdertyd motiveer om ander uitdagings, soos ongeduld, te hanteer $(\mathrm{f}=4)$.

- Kliënte se weerstand word makliker afgebreek. Dit is moontlik aangesien die kliënt nie net met probleme gekonfronteer word nie. Voorts kan dit daartoe aanleiding gee dat die kliënt andere minder blameer vir sy omstandighede $(\mathrm{f}=4)$. 
- Maatskaplikewerk-dienste, ooreenkomstig 'n sterkteperspektief, bevorder die wedersydse vertroue tussen die kliënt en die maatskaplike werker omdat die vennootskap, waarin dié partye betrokke is, vertroue stimuleer $(\mathrm{f}=3)$.

- Die alkoholafhanklike persoon word meer aktief by die oplossing van uitdagings betrek as wat die geval is met ander praktykbenaderings. Die sterkteperspektief voorkom dus dat die kliënt andere, soos sy vrou, blameer vir sy drankprobleem $(\mathrm{f}=2)$.

- Die kliënt word aktief betrek by doelwitformulering. Gevolglik ervaar die kliënt dikwels dat sy behoeftes bevredig word $(\mathrm{f}=1)$.

- Maatskaplikewerk-dienste vanuit 'n sterkteperspektief bevorder die benutting van hulpbronne. Die maatskaplike werker en kliënt is dus nie alleen verantwoordelik vir sukses nie, maar word ondersteun deur gemeenskapsterktes $(\mathrm{f}=1)$.

Vanuit die voorafgaande word die afleiding gemaak dat die maatskaplikewerk-deelnemers verskeie voordele voorsien waar 'n maatskaplikewerk-praktyk volgens 'n sterkteperspektief funksioneer. Soos reeds aangedui, word hierdie perspektief egter nog min in die praktyk toegepas.

Benewens die bogenoemde, kom die volgende aanvullende voordele ook uit die literatuur na vore (Chazin, Kaplan \& Terio, 2000:198-200; Graybeal, 2001:234; Lewis, 1996:101; Orsulic-Jeras, Shepherd \& Britton, 2003:240; Pray, 1991:82-84; Rapp, 1998:5-7, Saleebey, 2004:589-590; Sullivan \& Fisher, 1994:66; Van Wormer, 1999:5-6):

- Die kliënt se sterktes word deur die maatskaplike werker erken en gerespekteer. Hierdeur voel die kliënt bemagtig om sy eie asook kollektiewe kragte en potensiaal te benut om uitdagings te hanteer. Dit is veral van belang vir die bejaarde kliënt aangesien dit suksesvolle veroudering kan bevorder.

- Die maatskaplike werker erken die kliënt as 'n outoriteit met kennis en begrip van sy eie situasie. Hierdie kennis word geakkommodeer in maatskaplikewerk-dienslewering, aangesien maatskaplike werkers nie as onafhanklike deskundiges dienste lewer nie, maar wel die kennis en insigte van die kliënt benut in die bemagtigingsproses.

- Die sterkteperspektief verhoed die stereotipering van kliënte deur maatskaplike werkers. Die uniekheid van elke kliënt word onvoorwaardelik erken en benut in die bemagtigingsproses. Dit geld eweneens vir die alkoholafhanklike bejaarde.

- Op die lange duur belê die maatskaplike werkers in die voortgesette doeltreffende maatskaplike funksionering van die kliënt. Die kliënt leer om sy sterktes te identifiseer, te organiseer en te gebruik asook gemeenskapshulpbronne, soos ondersteuningsgroepe van die $\mathrm{CAD}$, te benut.

- Diversiteit word as 'n sterkte in maatskaplikewerk-dienslewering beskou en nie as 'n kompliserende faktor nie. Kliënte se kulturele gebruike kan hulle bemagtig om struikelblokke te oorkom, byvoorbeeld die oorbrugging van depressie deur 'n reinigingseremonie as deel van die rousmartproses.

\section{Nadele}

Die maatskaplikewerk-deelnemers $(\mathrm{N}=27)$ is ook gevra om die nadele van maatskaplikewerkdienslewering, ooreenkomstig die sterkteperspektief, aan te dui. Die kwalitatiewe response op hierdie vraag was soos volg: 
- Kliënte mag voel dat hulle werklike probleem, soos alkoholisme, ontken word in die maatskaplikewerk-dienslewering. Dit mag gevolglik weerstand in die hand werk $(\mathrm{f}=5)$.

- Arrogansie mag by kliënte ontwikkel. Die kliënt wat te goed oor homself voel, kan moontlik arrogant optree teenoor sy naasbestaandes asook diensverskaffers deurdat hy hulle menswaardigheid kan aantas met onwelvoeglike opmerkings $(\mathrm{f}=4)$.

- Die maatskaplike werker sowel as die kliënt mag onrealistiese verwagtinge koester. 'n Voorbeeld van 'n onrealistiese verwagting sal wees dat 'n alkoholafhanklike bejaarde wil terugkeer na sy beroep as wynbemarker en van mening is dat hy nie weer alkohol sal gebruik nie. Die persoon wat wyn as drank bemark, moet dit noodwendig ook drink om die eienskappe daarvan met die potensiële koper te deel $(\mathrm{f}=4)$.

- Die sterkteperspektief ignoreer die probleme in die kliënt se lewe aangesien die maatskaplike werker hoofsaaklik sterktes moet assesseer $(\mathrm{f}=3)$.

- Die hulpverleningsproses is te lank omdat die maatskaplike werker benewens probleme ook nog op sterktes moet konsentreer. Maatskaplikewerk-dienslewering ooreenkomstig 'n mediese benadering is meer vaartbelyn $(\mathrm{f}=2)$.

- Die sterkteperspektief is té filosofies om werklik 'n komplekse toestand soos alkoholisme te behandel $(\mathrm{f}=2)$.

- Maatskaplikewerk-dienslewering vanuit 'n sterkteperspektief vereis dikwels van die kliënt om self sy sterktes te identifiseer. Kliënte besit dikwels nie die vermoë tot sterkte-identifikasie nie $(\mathrm{f}=1)$.

Blundo (2001:302), Brun en Rapp (2001:280); Clark (1997:2), De Jong en Miller (1995:729), Kivnick en Murray (2001:26), McMillen et al. (2004:317-318), McQuaide en Ehrenreich (1997:211), Meinert, Pardeck en Murphy (1998:50-53), Orsulic-Jeras et al. (2003:241-242), Saleebey (1996:302-303), Saleebey (2002b:267-276) asook Weick en Chamberlain (2002:95) meen dat nadele soos die bogenoemde algemeen uitgespreek word, maar verdedig dié argumente soos volg:

- Ten spyte van talle lewensprobleme beskik alle individue, groepe en gemeenskappe oor sterktes.

- Die maatskaplike werker mag nooit 'n beperking op die kliënt se vermoëns plaas nie. Die standpunt is die sogenaamde "the sky is the limit".

- Die sterkteperspektief ontken nie probleme soos alkoholisme nie. Dit stel egter 'n maatskaplikewerk-praktyk voor waarin kliënte se probleme, sterktes en potensiaal verken word.

- Die sterkteperspektief stel die maatskaplike werkers in staat om binne so min as vyf onderhoude 'n fasiliteringsproses te inisieer en te termineer. Dit is dus allermins 'n langdradige hulpverleningsproses.

- Die sterkteperspektief verskaf hoop aan kliënte deur hul te oortuig dat uitdagings hanteer kan word met die benutting van sterktes soos deursettingsvermoë.

- Vanweë die dominante aanwending van probleemgesentreerde benaderings word die sterkteperspektief dikwels onregverdig beskuldig dat dit objektiewe realiteite ignoreer. 
Vanuit die voorafgaande bespreking het dit duidelik aan die lig gekom dat die sterkteperspektief voordele vir die maatskaplike werker en die kliënt inhou. Daarbenewens is verskeie nadele van hierdie perspektief aangetoon.

\section{GEVOLGTREKKINGS}

Op grond van die voorafgaande bevindings word daar tot die volgende gevolgtrekkings gekom:

- Die sterkteperspektief stel voor dat maatskaplike werkers onvoorwaardelik moet glo in kliënte se vermoë om te groei, te verander en te ontwikkel. Dit lei tot die gevolgtrekking dat die sterkteperspektief nie noodwendig 'n nuwe gedagte in die Maatskaplike Werk is nie omdat dit gebaseer is op beginsels wat reeds oor dekades heen onderskryf word .

- Met die literatuurstudie is bevind dat die sterkteperspektief reeds benut word op uiteenlopende terreine van maatskaplikewerk-dienslewering. Teen hierdie agtergrond word tot die gevolgtrekking gekom dat die sterkteperspektief ook geskik behoort te wees vir alkoholafhanklike bejaardes wat soms foutiewelik geëvalueer word as mense met 'n swak prognose .

- Hoewel verskeie outeurs uiteenlopende bydraes oor die sterkteperspektief lewer, ontbreek 'n standaard definisie daarvoor. Die gevolgtrekking word gemaak dat dié perspektief té resent is om reeds in vaktaalwoordeboeke gedefinieer te wees.

- In die uitvoering van die empiriese ondersoek is beide die bejaarde en maatskaplikewerkdeelnemers versoek om die sterktes van alkoholafhanklike bejaarde persone te vermeld. Vanuit die kwalitatiewe en kwantitatiewe response is bevind dat die bejaardes oor sterktes soos lewenswysheid beskik. Op grond van hierdie bevindings word tot die gevolgtrekking gekom dat alkoholafhanklike bejaardes oor sterktes beskik wat tydens maatskaplike groepwerk met vrug benut kan word.

- Vanuit die empiriese ondersoek is bevind dat die maatskaplikewerk-deelnemers verbonde aan geregistreerde behandelingsentra in Suid-Afrika meestal nie bekend is met die sterkteperspektief nie. Daar is ook bevind dat die maatskaplikewerk-deelnemers enersyds nie hierdie perspektief in dienslewering benut nie, aangesien hulle nie daarmee bekend is nie. Andersyds funksioneer die multiprofessionele spanne, waarvan hul deel is, meestal ooreenkomstig 'n probleemgesentreerde benadering. Indien hierdie bevinding vir alle geregistreerde behandelingsentra in Suid-Afrika geld, is die kanse skraal dat die sterkteperspektief in sodanige sentra figureer. Dit is enersyds weens die maatskaplike werkers se onbekendheid daarmee, en andersyds weens 'n probleemgesentreerde benadering wat die fasilitering van alkoholafhanklike bejaardes tans oorheers.

- Vanuit die literatuurstudie en empiriese ondersoek is bevind dat die sterkteperspektief verskeie voordele inhou vir die alkoholafhanklike bejaarde. Op grond hiervan is dit duidelik dat die sterkteperspektief oor eienskappe beskik wat tot voordeel van alkoholafhanklike bejaardes strek. Dit bied ruimte vir die erkenning van dié persone se besondere behoeftes en eienskappe asook eiesoortige omstandighede wat hul van ander alkoholiste onderskei.

- Daar is ook bevind dat dié perspektief soms met nadele gepaardgaan. Kliënte se sterktes kan in só 'n mate geaksentueer word dat hulle mag voel hul werklike probleem, alkoholisme, word deur die maatskaplike werker ontken. Teen hierdie agtergrond word tot die gevolgtrekking gekom dat die sterkteperspektief ook die kliënt mag benadeel, indien die 
maatskaplike werker nie die volle implikasies van die perspektief in ag neem en dit tot voordeel van die kliëntsisteem benut nie.

- Die sterkteperspektief figureer reeds die afgelope dekade in die Suid-Afrikaanse welsynsbeleid, maar die meeste maatskaplikewerk-deelnemers is nie daarmee bekend nie. Die gevolgtrekking word gemaak dat geregistreerde behandelingsentra steeds probleemgesentreerd werk, terwyl hulle voorgee om 'n ontwikkelingsmodel, per implikasie ook 'n sterkteperspektief, te ondersteun en toe te pas. Die moontlikheid bestaan dat die staat om die bos gelei word ter wille van volgehoue subsidies.

\section{AANBEVELINGS}

Op grond van die voorafgaande bevindings en gevolgtrekkings word die volgende aanbevelings gemaak:

- Maatskaplikewerk-praktisyns verbonde aan geregistreerde behandelingsentra in Suid-Afrika sowel as behandelingsentra wat deur die staat bedryf word, behoort opgelei te word om die sterkteperspektief sinvol in maatskaplikewerk-dienste te benut. Die rede hiervoor is dat daar in hierdie ondersoek bevind is dat die sterkteperspektief oor kwaliteite beskik wat tot voordeel van dié kliëntsisteem aangewend kan word.

- Afgesien van die voorgenoemde maatskaplikewerk-praktisyns, behoort lede van die multiprofessionele span eweneens in die aard en praktyk van die sterkteperspektief opgelei te word. Die rede hiervoor is dat die sterkteperspektief oor kwaliteite beskik deur middel waarvan aandag aan die eiesoortige behoeftes, sterktes en uitdagings van alkoholafhanklike bejaardes gegee kan word, soos om onvoorwaardelik te glo in hulle vermoë om te groei, te verander en te ontwikkel.

- 'n Nasionale liggaam, soos die Suid-Afrikaanse Nasionale Raad vir Alkoholisme en Afhanklikheid van Verdowingsmiddels (SANRA), behoort navorsingskomitees, bestaande uit maatskaplikewerk-praktisyns, te benoem om die kwaliteite en toepassingsmoontlikhede van die sterkteperspektief te ondersoek. Indien die sterkteperspektief suksesvol blyk te wees, behoort hierdie navorsingsresultate by wyse van onder meer omsendbriewe en vaktydskrifpublikasies tot die beskikking van maatskaplike werkers, verbonde aan geregistreerde behandelingsentra in Suid-Afrika, gestel te word. Daarbenewens behoort dié bevindings tot die beskikking van maatskaplikewerk-opleidingsinstansies in Suid-Afrika gestel te word. So kan student-maatskaplikewerkers met relevante kennis en vaardighede toegerus word om hulle voor te berei vir die eise wat die beginnerspraktyk, rakende die bemagtiging van alkoholafhanklike bejaardes, stel. Die Potchefstroomkampus van die Noordwes-Universiteit en die Universiteit van die Vrystaat bied reeds kortkursusse aan in dié perspektief.

- Die sterktes van alkoholafhanklike bejaardes behoort aangewend te word in die ontwikkeling en aanbieding van 'n maatskaplike groepwerk-bemagtigingsprogram met alkoholafhanklike bejaardes, aangesien dit heel moontlik tot dié kliëntegroep se voordeel kan wees. Sodanige voordele behoort met intervensie navorsing bepaal te word.

- Die sterktes wat in hierdie artikel geïdentifiseer is, kan vergelyk word met dié van alkoholafhanklike bejaardes in ander Afrika- en ontwikkelende lande sodat idees, rondom dienste aan dié kliëntegroep ooreenkomstig 'n sterkteperspektief, uitgeruil kan word tussen maatskaplike werkers. 


\section{SLOTOPMERKINGS}

Op grond van die voorafgaande word daar tot die gevolgtrekking gekom dat alkoholafhanklike bejaardes oor heelwat sterktes beskik wat onder meer in maatskaplike groepwerkdienste aangewend kan word. Daarbenewens het dit aan die lig gekom dat die sterkteperspektief oor verskeie kwaliteite beskik wat tot voordeel van alkoholafhanklike bejaardes benut kan word.

\section{BIBLIOGRAFIE}

BABBIE, E. 2004. The practice of social research $\left(10^{\text {th }}\right.$ ed $)$. Belmont, CA.: Wadsworth/Thomson Learning.

BLUNDO, R. 2001. Learning strengths-based practice: challenging our personal and professional frames. Families in society, 82(3):296-304.

BRUN, C. \& RAPP, R.C. 2001. Strengths-based case management: individuals' perspectives on strengths and the case manager relationship. Social Work, 46(3):278-288.

CHAZIN, R., KAPLAN, S. \& TERIO, S. 2000. Introducing a strengths/resiliency model in mental health organizations. In: NORMAN, E. (ed) Resiliency enhancement: putting the strengths perspective into social work practice. Chichester, N.Y.: Columbia University Press.

CLARK, M.D. 1997. Strengths-based practice: the new paradigm. Corrections Today, 59(2):110113, Apr. Available: Academic Search Premier. [Date of access: 24 Jan. 2003].

COWGER, C.D. \& SNIVELY, C.A. 2002. Assessing client strengths: individual, family and community empowerment. In: SALEEBEY, D. (ed) The strengths perspective in social work practice $\left(3^{\text {rd }} \mathrm{ed}\right)$. Boston: Allyn and Bacon.

DE JONG, P. \& MILLER, S.D. 1995. How to interview for client strengths. Social Work, 40(6):729-736.

DELPORT, C.S.L. \& FOUCHÉ, C.B. 2005. The place of theory and the literature review in the qualitative approach to research. In: DE VOS, A.S. (ed) Research at grass roots $\left(3^{\text {rd }}\right.$ ed). Pretoria: Van Schaik.

DE VOS, A.S. 2005a. Qualitative data analysis and interpretation. In: DE VOS, A.S. (ed) Research at grass roots $\left(3^{\text {rd }} \mathrm{ed}\right)$. Pretoria: Van Schaik.

DE VOS, A.S. 2005b. Combined quantitative and qualitative approach. In: DE VOS, A.S. (ed) Research at grass roots $\left(3^{\text {rd }} \mathrm{ed}\right)$. Pretoria: Van Schaik.

EARLY, T.J. \& GLENMAYE, L.F. 2000. Valueing families: social work practice with families from a strengths perspective. Social Work, 45(2):118-130.

GRAY, M. \& VAN ROOYEN, C.A.J. 2002. The strengths perspective in social work: lessons from practice. Social Work/Maatskaplike Werk, 38(3):193-201.

GRAYBEAL, C. 2001. Strengths-based social work assessment: transforming the dominant paradigm. Families in Society, 82(2):233-242.

KISTHARDT, W.E. 2002. The strengths perspective in interpersonal helping: purpose, principles and functions. In: SALEEBEY, D. (ed) The strengths perspective in social work practice $\left(3^{\text {rd }}\right.$ ed). Boston: Allyn and Bacon.

KIVNICK, H.Q. \& MURRAY, S.V. 2001. Life strengths interview guide: assessing elder clients' strengths. Journal of Gerontological Social Work, 34(4):7-31. 
KOTZE, G.J. 2002. Die generiese basis van gevorderde maatskaplikewerk-praktyk (MWKM874). Potchefstroom: PU vir CHO. (Studiegids.)

KOTZE, G.J. 2003. Armoedegesentreerde dienslewering (MWK411). Potchefstroom: PU vir CHO. (Diktaat D9/2003.)

LEWIS, J.S. 1996. Sense of coherence and the strengths perspective with older persons. Journal of Gerontological Social Work, 26(3/4):99-112.

LOMBARD, A. 1996. Developmental social welfare in South Africa: a theoretical framework. Social Work/Maatskaplike Werk, 32(2):162-172.

McMILLEN, J.C., MORRIS, L. \& SHERRADEN, M. 2004. Ending social work's grudge match: problems versus strengths. Families in Society, 85(3):317-325.

McQUAIDE, S. \& EHRENREICH, J.H. 1997. Assessing clients strengths. Families in Society, 78(2):201-212.

MEINERT, R.G., PARDECK, J.T. \& MURPHY, J.W. 1998. Introduction to postmodernism, religion and the future of social work. In: MEINERT, R.G., PARDECK, J.T. \& MURPHY, J.W. (eds) Postmodernism, religion and the future of social work. Binghamton, N.Y.: Haworth Pastoral Press.

MITCHELL, M. \& JOLLEY, J. 2001. Research design explained (4 ${ }^{\text {th }}$ ed). Fort Worth: Harcourt College Publishers.

MKHWANAZI, H.F. \& TRIEGAARDT, J. 2003. Reconceptualisation of social work: a study in Johannesburg. The Social Work Practitioner-Researcher/Die Maatskaplikewerk-NavorserPraktisyn, 15(1):48-60.

MONETTE, D.R., SUlLIVAN, T.J. \& DEJONG, C.R. 2005. Applied social research: A tool for the human services $\left(6^{\text {th }}\right.$ ed). Belmont, CA.: Brooks/Cole-Thomson Learning.

MURPHY, J.W. \& PARDECK, J.T. 1998. Renewing social work practice through a postmodern perspective. In: MEINERT, R.G., PARDECK, J.T. \& MURPHY, J.W. (eds) Postmodernism, religion and the future of social work. Binghamton, N.Y.: Haworth Pastoral Press.

NORMAN, E. 2000. Introduction: the strengths perspective and resiliency enhancement. In: NORMAN, E. (ed) Resiliency enhancement: putting the strengths perspective into social work practice. Chichester, N.Y.: Columbia University Press.

ORSULIC-JERAS, S., SHEPHERD, J.B. \& BRITTON, P.J. 2003. Counseling older adults with HIV/AIDS: a strengths-based model of treatment. Journal of Mental Health Counseling, 25(3):233-244.

PARDECK, J.T. \& MURPHY. J.W. 1993. Postmodernism and clinical practice: a critical analysis of the disease model. Psychological Reports, 72:1187-1194.

PATEL, L. \& WILSON, T. 2003. A perspective on the transformation of social welfare 19942002. The Social Work Research-Practitioner/Die Maatskaplikewerk-Navorser-Praktisyn, 15(3):219-232.

POTGIETER, M.C. 1973. Maatskaplike sorg in Suid-Afrika. Stellenbosch: Universiteitsuitgewers en -boekhandelaars. 
PRAY, J.E. 1991. Respecting the uniqueness of the individual: social work practice within a reflective model. Social Work, 36(1):80-85.

RAPP, C.A. 1998. The strengths model: case management with people suffering from severe and persistent mental illness. Oxford, N.Y.: Oxford University Press.

RAPP, R.C. 2002. Strengths-based case management: enhancing treatment for persons with substance abuse problems. In: SALEEBEY, D. (ed) The strengths perspective in social work practice $\left(3^{\text {rd }}\right.$ ed $)$. Boston: Allyn and Bacon.

RHODES, R. \& JOHNSON, A.D. 1996. Social work and substance abuse treatment: A challenge for the profession. Families in Society, 77(3):182-185.

SA $k y k$ SOUTH AFRICA.

SALEEBEY, D. 1996. The strengths perspective in social work practice: extensions and cautions. Social Work, 41(3):296-305.

SALEEBEY, D. 2001. Practicing the strengths perspective: everyday tools and resources. Families in Society, 82(3):221-222.

SALEEBEY, D. 2002a. Introduction: power in the people. In: SALEEBEY, D. (ed) The strengths perspective in social work practice $\left(3^{\text {rd }}\right.$ ed). Boston: Allyn and Bacon.

SALEEBEY, D. 2002b. The strengths perspective: possiblities and problems. In: SALEEBEY, D. (ed) The strengths perspective in social work practice $\left(3^{\text {rd }}\right.$ ed). Boston: Allyn and Bacon.

SALEEBEY, D. 2004. Response to “Ending social work's grudge match.” Families in Society, 85(4):588-590.

SAS INSTITUTE INC. 2002. The SAS System for Windows Release 9.1 TS Level 1MO Copyright @ 2002-2005 by SAS Institute Inc., Cary, NC, USA.

SMITH, L. 2002. Respecting the cultural contact as a strength in social work intervention. (Voordrag gelewer as deel van die jaarlikse Gesamentlike Universiteite Kongres vir Maatskaplike Werk op 11 September 2002.) Potchefstroom. (Ongepubliseer.)

SOUTH AFRICA. Department of Welfare. 1997. White paper for social welfare. Government Gazette, 18166, 8 Aug.

SOUTH AFRICA. Department of Welfare. 1999. National drug master plan. Pretoria: CTP Book Printers.

STRYDOM, H. 2000. Maatskaplikewerk-navorsing (MWK 321/411). Potchefstroom: PU vir CHO. 268 p. (Diktaat.)

STRYDOM, H. 2005a. Ethical aspects of research in the social sciences and human service professions. In: DE VOS, A.S. (ed) Research at grass roots $\left(3^{\text {rd }}\right.$ ed). Pretoria: Van Schaik.

STRYDOM, H. 2005b. Sampling and sampling methods. In: DE VOS, A.S. (ed) Research at grass roots $\left(3^{\text {rd }} \mathrm{ed}\right)$. Pretoria: Van Schaik.

SULLIVAN, W.P. \& FISHER, B.J. 1994. Intervening for success: strengths-based case management and successful aging. Journal of Gerontological Social Work, 22(1/2):61-74.

VAN DYK, A.C. 2001. Welsynskunde en bestuur. (SCK101-W \& WF101-E). Pretoria: Unisa. (Studiegids.) 
100

VAN EEDEN, E.S., RYKE, E.H. \& DE NECKER, I.C.M. 2000. The welfare function of the South African government before and after apartheid. Social Work/Maatskaplike Werk, 36(1):124.

VAN WORMER, K. 1999. The strengths perspective: a paradigm for correctional counseling. Federal probation, 0014-9128, 63(1):1-12, Jun. Available: Academic Search Premier. [Date of access: 12 Feb. 2005].

VAN WORMER, K. \& DAVIS, D.R. 2003. Addiction treatment: a strengths perspective. Pacific Grove, Calif.: Brooks/Cole.

WALLER, M.A. 2001. Resilience in ecosystemic context: evolution of the concept. American Journal of Orthopsychiatry, 71(3):1-25.

WEICK, A. \& CHAMBERLAIN, R. 2002. Putting problems in their place: further explorations in the strengths perspective. In: SALEEBEY, D. (ed) The strengths perspective in social work practice $\left(3^{\text {rd }}\right.$ ed). Boston: Allyn and Bacon.

WEICK, A. \& SALEEBEY, D. 1998. Postmodern perspectives for social work. In: MEINERT, R.G., PARDECK, J.T. \& MURPHY, J.W. (eds) Postmodernism, religion and the future of social work. Binghamton, N.Y.: Haworth Pastoral Press.

WEICK, A., RAPP, C., SULLIVAN, W.P. \& KISTHARDT, W. 1989. A strengths perspective for social work practice. Social Work, 34:350-354.

Dr Stephan Geyer was 'n PhD-kandidaat in die Vakgroep Maatskaplike Werk, Noordwes-Universiteit, Potchefstroomkampus, Suid-Afrika, met die uitvoering van die ondersoek. Prof Herman Strydom, Vakgroep Maatskaplike Werk, Noordwes-Universiteit, Potchefstroomkampus, Suid-Afrika. 